\title{
CRIANÇAS INVISÍVEIS: Um filme sobre a violência em suas múltiplas formas
}

\author{
A ll the invisible children: A movie about violence and its multiple types
}

Cucinotta, M. G., Tilesi, C., Veneruso, S. (Produtores), Charef, M., Lund, K., Kusturica, E., Charef, M., Veneruso, S.,Woo, J.; Lee, S., Scott, J., Scott, R. (Diretores) (2005). Crianças invisíveis. [filme]. França/ Itália.

\section{Ana Carina Stelko Pereira, Lúcia Cavalcanti de Albuquerque Williams ${ }^{b}$}

\footnotetext{
a Psicóloga e Mestranda em Educação E special pelo Programade Pós-G raduação em Educação Especial da Universidade Federal de São Carlos (UFScar), Bolsista mestrado da FAPE SP, São Carlos, SP - Brasil, email: anastelko@ gmail.com

${ }^{\text {b }}$ D outora em Psicologia Experimental (USP), Professora Titular do D epartamento de Psicologia da UFSCAR eCoordenadora do Laboratório de Análise e Prevenção da Violência (LAPREV), São Carlos, SP - Brasil, email: williams@ power.ufscar.br
}

Crianças invisíveis não é um filme recente, foi produzido em 2005, sem fins lucrativos e acabou sendo pouco divulgado. No entanto, é um dos filmes imperdíveis, em especial, para o psicólogo, pois descreve 0 cenário infanto-juvenil de vários países, no âmbito de um tema que necessita de maior debate no campo da Psicologia brasileira: a violência, suas várias modalidades e consequências.

Não se trata de um filme técnico, configurando-se no gênero drama, o que possibilita uma apreensão mais emotiva dos problemas acarretados pela violência. O utro ponto positivo do filme foi ter sido realizado sem apelo comercial e publicitário, tendo os diretores maior liberdade de criação. 0 dinheiro arrecadado foi doado à UNICEF e a uma organização mundial que busca combater a fome (W orld Food Program).

0 filme é composto de sete curtas-metragens realizados em países desenvolvidos e em desenvolvimento. Percebe-se que o filme como um todo aborda a definição de violência explicitada pela Organização Mundial da Saúde (1998), a qual divide a violência em três categorias: 1) a autoafligida: violência contra si mesmo, sendo o suicídio o modo mais fatal, 2) a interpessoal: comportamento violento entre indivíduos, os quais podem ser íntimos ou não e 3) a organizada: comportamento violento de grupos sociais ou políticos, motivados por objetivos políticos, econômicos ou sociais.

0 primeiro curta-metragem filmado na Africa, do diretor Mehdi Charef, revela a realidade de meninos-soldados, envolvidos em conflitos étnicos, políticos e econômicos. 0 contraste entre a realidade vivida pelos meninos-soldados e aquilo que comumente se entende por infância - período em que o indivíduo 
deve ser protegido, cuidado, está em formação - é chocante. A situação apresentada pode parecer aos brasileiros uma realidade distante, contudo, as quadrilhas do tráfico nas favelas do Rio de Janeiro, deacordo com D owdney (2003), empregam menores de idade em várias funções, entre elas: monitorar uma região da favela, avisando quando entram policiais emembrosinimigos; venderdrogas; manter a ordem na comunidade e proteger empregados das facções. Ainda de acordo com D owdney (2003, p. 135), a utilização de crianças e adolescentes em combates armados aumentou a partir da década de 70, em razão da competição violenta entre grupos rivais, com a morte de muitos adultos, do aumento da disponibilidade de armas e do fato de que "as crianças são ágeis, rápidas, pequenas, muitas vezes intrépidas, podem usar armas leves com eficiência, se não com precisão, e são difíceis de manter presas quando detidas."

0 segundo curta-metragem filmado na Sérvia Montenegro, e dirigido por Emir Kusturica, revela a situação de garotos em conflito com a lei que se encontram com a liberdade cerceada, em instituição de reabilitação. O curta explora a dificuldade de fazer cumprir os objetivos desse tipo de instituição, como também, aponta algumas das variáveis que promovem comportamentos delituosos. As variáveis descritas estão em consonância com a literatura científica, conforme revisada por Gallo e Williams (2005): violência familiar, baixos níveis de afeto e coesão na família, alcoolismo de cuidadores, indiferença generalizada pelos responsáveis, reduzido status socioeconômico, associação com pessoas agressivas ou usuários de drogas, distanciamento de pessoas que não se comportam criminalmente.

0 terceiro curta-metragem, norteamericano, do diretor Spike Lee, alude à realidade de crianças que estão expostas aos seguintes fatores de risco: ser portador do vírus HIV, ter pais que fazem uso/abuso de substâncias ilícitas, residir em bairros pobres e violentos e ser vítima de violência escolar. 0 interessante é que esse curtametragem contextualiza tal realidade socialmente, não negando a responsabilidade individual, mas explorando como a participação como combatente na guerra do Iraque, a falta de oportunidade de emprego, a carência de recursos de assistência social, a pouca informação da população a respeito do HIV influenciam para que a personagem central tivesse uma vida difícil.
0 quarto curta-metragem, brasileiro, dirigido por Kátia Lund, aponta um tipo de violência cujo agressor é difícil de identificar. É a violência em que as crianças devem trabalhar para manter 0 seu sustento e ajudar a pagar as despesas familiares, sendo expostas a situações de perigo para seu desenvolvimento físico e psicológico. Além disso, o curta é brilhante ao apontar a capacidade de resiliência das crianças e ao mostrá-las com comportamentos comumente mais relacionados à infância, como o brincar.

0 quinto curta-metragem, inglês e de direção de Ridley e Jordon Scott, faz o exercício de um adulto, o qual fotografa guerras, de se colocar em uma posturainfantil, compreendendo o mundo como uma criança o faria. Tal curta valoriza a simplicidade do mundo infantil, o qual permite intercâmbios e discussões, sem que se façam conflitos permanentes, contrasta abruptamente com o mundo adulto apresentado, no qual a aceitação das diferenças parece inatingível e permeada de complexidade, em que necessita da atuação de diversas organizações e governos. Um dos curtas-metragens mais enigmáticos do filme, explora habilmente o problema da violência organizada, demonstrando que esta não é circunscrita à situação de conflito, tendo efeitos no âmbito individual e intergeracional.

0 penúltimo curta-metragem, dirigido por Stefano Veneruso e filmado na Itália, se refere à situação de adolescentes vítimas de alguns dos tipos de maus-tratos descritos pela Sociedade Internacional para a Prevenção do Abuso Infantil e Negligência (International Society for Prevention of Child A buse and Neglect, 2006). O personagem principal sofre de negligência por parte dos cuidadores, sendo violentado psicologicamente, xingado e depreciado. Ele encontra aceitação social e garantia das necessidades alimentares em um grupo deadolescentes antissocial, quefaz pequenos roubos. Contudo, o curta não descreve a situação pelo senso comum, explorando ao máximo os sentimentos do adolescente decorrentes da situação em que se encontra, chegando a simular o suicídio do garoto, por meio de uma brincadeira que este faz com a própria sombra.

O último curta-metragem, produzido na China, dirigido por John Woo, aponta para o fato de 0 conflito e a violência não se restringem à classe social pobre. 0 curta-metragem contrastaarealidade de duas meninas, sendo que uma é de classe sócio- 
econômica alta, enquanto que a outra tem poder aquisitivo muito baixo. A história apresentada é marcante na alusão a sonhos, fantasias e gestos simples que adquirem importância como geradores de esperança e motivadores de mudanças positivas significativas.

Não sem razão, o último curta-metragem termina o filme com uma mensagem de esperança. Interpreta-se que a intenção do filme não foi apenas de revelar situações de violência em que crianças e adolescentes estão envolvidos, como, também, de estimular acões de mudanç. Assim, tal filme invoca uma consideração sobre o psicólogo.

O psicólogo é aquele que atua em diferentes contextos (em consultório, hospital, empresa, escola, organizações, no esporte, na comunidade, no trânsito, etc.) e, dada as sequelas ao desenvolvimento infantil, tem aobrigação deestaratento paraidentificarrelações de violência, especialmente aquelas em que crianças e adolescentes estão envolvidos, realizar intervenções a fim de diminuí-la, amenizar as consequências dela advindas e, principalmente, prevenir situações de violência. $\mathrm{O}$ filme $\mathrm{C}$ rianças Invisíveis pode servir como um estímulo para que a questão da violência tenha mais notoriedade para os psicólogos e, espera-se, também, que sirva de incentivo para que estes se sensibilizem com a temática de forma a aprofundar 0 conhecimento sobre esta e os modos de intervir, remediar e preveni-la.

\section{REFERÊNCIAS}

D owdney, L. (2003). Crianças do tráfico: Um estudo de caso de crianças em violência armada organizada no Rio de Janeiro. Rio de Janeiro: Sete Letras.

Gallo, A. E., \& Williams, L. C. A. (2005). Adolescentes em conflito com a lei: uma revisão dos fatores de risco para a conduta infracional. Psicologia: Teoria e Prática, 7(1), 81-95.

International Society for Prevention of Child Abuse and Neglect (2006). Survey of key informants. In D. D aro. (O rg.). World perspectives on child abuse. (pp. 7-38). ISPCAN: Recuperado em 15 jul. 2008: http:/ / www.ispcan.org/ wp/ index.htm

O rganização Mundial da Saúde. (1998). Violence prevention: An important element of a health-promoting school. Recuperado em 13 abr. 2007: http:/ / www.who.int/ school_youth_health/media/ en/ 93.pdf

Recebido: 22/ 08/ 2008 Received: 08/ 22/ 2008

Aprovado: $23 / 09 / 2008$ A pproved: 09/23/ 2008 